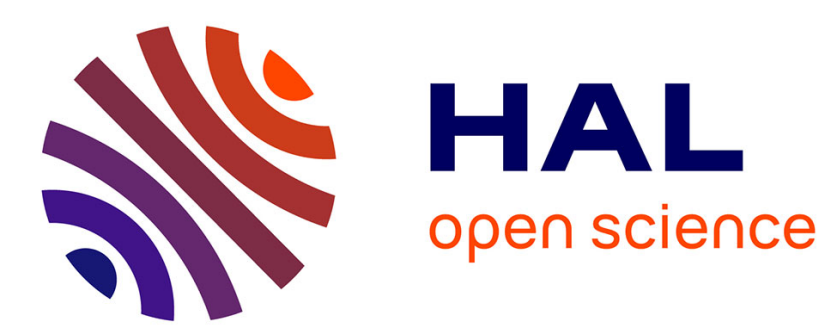

\title{
Nasal carriage of Staphylococcus aureus in dairy sheep.
}

\author{
E. Vautor, G. Abadie, J.-M. Guibert, N. Chevalier, Michel Pépin
}

\section{To cite this version:}

E. Vautor, G. Abadie, J.-M. Guibert, N. Chevalier, Michel Pépin. Nasal carriage of Staphylococcus aureus in dairy sheep.. Veterinary Microbiology, 2005, 106 (3-4), pp.235-9. 10.1016/j.vetmic.2004.11.019 . hal-00409347

\section{HAL Id: hal-00409347 https://hal-anses.archives-ouvertes.fr/hal-00409347}

Submitted on 16 Nov 2009

HAL is a multi-disciplinary open access archive for the deposit and dissemination of scientific research documents, whether they are published or not. The documents may come from teaching and research institutions in France or abroad, or from public or private research centers.
L'archive ouverte pluridisciplinaire HAL, est destinée au dépôt et à la diffusion de documents scientifiques de niveau recherche, publiés ou non, émanant des établissements d'enseignement et de recherche français ou étrangers, des laboratoires publics ou privés. 
Short communication

Nasal carriage of Staphylococcus aureus in dairy sheep

E. Vautor*, G. Abadie, J-M. Guibert, N. Chevalier, M. Pépin

AFSSA (Agence Française de Sécurité Sanitaire des Aliments), Unité de Pathologie des Petits Ruminants, BP111, 06902 Sophia-Antipolis Cedex, France

* Author for correspondence and reprints :

Tel (33) 49294 3735; Fax (33) 492943701

E-mail address: e.vautor@sophia.afssa.fr 


\section{Abstract:}

The purpose of this study was to assess the prevalence of Staphylococus aureus nasal carriage of dairy sheep in farms producing cheeses manufactured with raw ewe's milk.

Moreover, we investigated the genetic diversity of the 136 isolates recovered from the anterior nares of the ewes, from the ambient air of the milking parlor and from cheeses. The isolates were typed using pulsed-field gel electrophoresis (PFGE) of DNA Smal digests.

The average nasal carriage in the flock was $29 \%$ of the nares of the ewes contaminated by Staphylococcus aureus. The genotyping results showed that strains with dominant pattern (named OV) and a genetically related isolates (named OV') by a majority (69.8\%) are recovered from nasal carriage in dairy sheep in this area of France. 
Key-words: Staphylococcus aureus; Pulsed-Field Gel Electrophoresis (PFGE); Ewe's nares; Genoptyping; Epidemiology

Understanding the epidemiology and the ecology of Staphylococcus aureus (S. aureus) [reservoirs, transmission pathways, and risk factors] has resulted in excellent control of this major mastitis pathogen in many cow herds. Milking time hygiene measures that decreased cow to cow transfer were largely responsible for decreasing new $S$. aureus intramammary infections. The most common transmission pathway consist of transfer from an infected mammary gland to an uninfected gland via fomites, such as milking equipment, common udder cloths, or the milker's hands. However, milking time hygiene alone was insufficient in controlling the disease. The addition of dry-cow therapy, and especially, culling the chronically infected were needed to achieve low level of $S$. aureus intrammmary infections. If there is little doubt that the primary and most important reservoir of $S$. aureus is the infected mammary gland, what about the others sources such the nares beside other sources as teat skin, udder skin, lips, eyes, vagina, rectum, sacral region, etc. It would suggest that total eradication of $S$. aureus in a flock is currently impossible (Roberson et al., 1994; Roberson et al., 1998). In 
Human disease, S. aureus nasal carriage has been extensively studied in patients and healthy individuals. Cross-sectional surveys of S. aureus nasal carriage have designated individuals as either carriers or noncarriers (Kluytmans et al., 1997).

Some authors have used the pulsed-field gel electrophoresis to genotype S. aureus colonising human nasal carriers (Hu et al., 1995). Less information is available about dairy sheep, even though it is likely that the ecology of $S$. aureus in a dairy sheep farm is probably the same than in a bovine or goat dairy farm (Vautor et al., 2003). In this study, we focus on one of a probable $S$. aureus reservoir of contamination of the udder represented by the nares of the ewes producing the milk for the manufacturing of the ewe's farm cheeses. We used the pulsed-field gel electrophoresis (PFGE) to investigate the genetic diversity of the nares' S. aureus isolates and to understand genetic relatedness between isolates recovered from different farms.

Between May 2003 and February 2004, in the south-east of France, ten farms (named A to J) were enrolled in the study. The farms were located at a distance of $15-200 \mathrm{~km}$ from each other and had no epidemiological links between them. The flock size varied from 30 to 230 ewes of French milking sheep breeds. General husbandry methods applied in these flocks were different, particularly regarding feeding, 
housing, or the presence of other animals on the farm, etc. Farms A-G had a mechanical milking procedure and farms $\mathrm{H}-\mathrm{J}$ had a hand milking procedure. The average number of milking ewes sampled in each flock was 37 . Thus, a total of 368 ewes were sampled: 227 in farms A to $G$ and 141 in farms $\mathrm{H}, \mathrm{I}, \mathrm{J}$. Ewes included in the study were sampled only once. Both the left and right anterior nares were swabbed by rubbing the dry cotton-wool swab inside of each nostril while applying an even pressure and rotating the swab. Within 2-5 hours the swabs were transported at $4^{\circ} \mathrm{C}$ and streaked directly on Baird-Parker rabbit plasma fibrinogen agar (BPRPFA) medium (BioMérieux, Marcy-l'Etoile, France), incubated for $12-48 \mathrm{~h}$ at $37^{\circ} \mathrm{C}$. Ambient air was sampled by using three plates (90mm in diameter) with BPRPFA medium exposed to the environment of the milking room for $15 \mathrm{~min}$ and incubated for $12-48 \mathrm{~h}$ at $37^{\circ} \mathrm{C}$. These plates were exposed, for all the farm, at $51 \mathrm{~cm}$ from above the ground of the milking room (at the udder level). Samples of cheese were plated on BPRPFA medium and incubated for 24-48 $\mathrm{h}$ as described by De Buyser (De Buyser et al., 1998). Confirmation of the identity of some isolates was performed, after demonstration of catalase positivity, by using the API STAPH system and Slidex®Stap Plus-Kit (BioMérieux, Marcy-l'Etoile, France). For the ewes' nares, only one colony was chosen for further analysis. Such procedures have been done, assuming that all morphologically similar colonies on a plate are formed by the 
same strain. For the air and cheese, up to five colonies were taken into account.

A macrorestriction analysis of the chromosomal DNA of the cultures was performed with the restriction enzyme Smal and subsequent pulsed-field gel electrophoresis. This genotyping system was chosen due to its high discriminatory power and excellent reproducibility (Tenover et al., 1994; Olive and Bean, 1999). A contour clamped homogeneous electrophoresis technique (CHEF) on the GenePath ${ }^{\mathrm{TM}}$ system (BIO-RAD Laboratories, California, USA) was used according to the instruction manual of the GenePath Group 1 reagent kit (BIO-RAD). Briefly, isolates of $\mathrm{S}$. aureus were transferred to a $\mathrm{BHI}$ broth and incubated overnight at $37^{\circ} \mathrm{C}$ in a shaking incubator. Bacterial cells were washed and resuspended in the cell suspension buffer (provided with the kit). The suspension was mixed with an equal volume of $1 \%$ chromosomal-grade agarose to make plugs. Bacterial cells were lysed in the resuspension buffer containing lysozyme $(25 \mathrm{mg} / \mathrm{ml})$ and lysostaphin $\left(2 \mathrm{mg} / \mathrm{ml}\right.$ ) after an incubation for $1 \mathrm{~h}$ at $37^{\circ} \mathrm{C}$. Then, $500 \mu \mathrm{l}$ of proteinase $\mathrm{K}$ buffer and $20 \mu \mathrm{l}$ of proteinase $\mathrm{K}(600 \mathrm{U} / \mathrm{ml})$ were added and the plugs were incubated for $16-20 \mathrm{~h}$ at $50^{\circ} \mathrm{C}$. The restriction enzyme Smal $(5 \mathrm{U} / \mu \mathrm{l})$ and its buffer were added and incubated for $16-20 \mathrm{~h}$ at $25^{\circ} \mathrm{C}$. Digests of DNA were separated during $20 \mathrm{~h}$ by PFGE using $1 \% \mathrm{gel}$ at the following 
conditions: $14^{\circ} \mathrm{C}, 120^{\circ}$ field angle, $6 \mathrm{~V} / \mathrm{cm}, 5-35 \mathrm{~s}$ pulse times. On each gel, two control plugs with the reference strain of S. aureus (strain CIP 57.10, Institut Pasteur, Paris, France) were included. Gels were stained with ethidium bromide (1 mg/ml) and photographed under UV light.

Isolates of S. aureus were placed in groups of identical or related strains by comparing, using visual examination, the banding patterns produced. The scheme used by Tenover (Tenover et al., 1995) was employed to differentiate between indistinguishable (zero band differences), closely related (1-3 band differences), possibly related (4-6 band differences) and unrelated or different ( $>6$ band differences) strains.

Among a total of 368 ewes' nares, $29 \%$ were positive for S. aureus. The detailed results of the bacteriological examination for each farm is given in table 1 . It is of interest to know the frequency of isolation, expressed as a percentage (number of positive $S$. aureus samples divided by total number of samples), because nasal carriage in dairy sheep may represent a major source of $S$. aureus for the contamination of milk's product, beside infected mammary gland. Although is could not be a direct contamination of the cheese it could serve as an important reservoir in the farm which could explain, despite strong hygienic procedures, the persistence of udder contamination. (Zecconi et al., 
2003). To our knowledge, no studies have been carried out in sheep dairy farms to assess the percentage of ewes' nasal carrier. In the general human population the authors agree in a mean carriage of $37.2 \%$ (13873 people) with variations according to population type (health care workers, patients hospitalised, drugs addicts, etc) and factors that may influence the rate of $S$. aureus nasal carriage (nasal abnormalities, age, hormonal status in women, ecology of nasal flora, viral infections of the upper respiratory tract, etc). In this general human population, the rate of $S$. aureus nasal carriage range from 19 to $55.1 \%$ (Kluytmans et al., 1997). Longitudinal studies, however, indicated that carriage patterns differ between individuals, and that 10 to $35 \%$ of individuals carry S. aureus persistently, 20 to $75 \%$ carry S. aureus intermittently, and 5 to $70 \%$ are persistently free of $S$. aureus (noncarriers) (Hu et al., 1995; Eriksen et al., 1995). The variation in reported rates results, at least partly, from differences in study populations, sampling and culture techniques, and criteria for the definition of persistent or intermittent carriage. To our knowledge, no studies have been carried out in dairy sheep, so the mean rate (29\%) found in our field survey couldn't been compared with other authors works. To identify for each ewe the carriage patterns (persistent, intermittent, and noncarriage), as determined by some authors for human being (VandenBergh et al., 1999), we should have obtained nasal 
ewe swab specimen during a 12-week follow-up period. Persistent nasal carriage is a unique characteristic of a fraction of the population, and the attribute "persistent" should be confined to those ewes for whom serial swab specimen cultures consistently yield S. aureus. The carrier state of each ewe could change over time. In human patients, the mean number of colony forming unit (CFU) of $S$. aureus that can be isolated from the anterior nares is higher in persistent carriers than in intermittent carriers, resulting in more extensive dispersal of staphylococci in the environment (White, 1961). In this field study, we found some ewes (11 ewes, data not shown) with high number of CFU (more than $100 \mathrm{CFU} / 23.7 \mathrm{~mm}^{2}$ ): these ewes are, perhaps, cases of persistent carriers. The others ewes (mean contamination with standard deviation $6.6+/-0.5 \mathrm{CFU} / 23.7 \mathrm{~mm}^{2}$ ) are intermittent carriers, probably contaminated by strains from ambient air. But, although the contamination rate of the ambient air had not been found high (only 5 farms/10 sampled were positive with S. aureus, at the height of $51 \mathrm{~cm}$ from the floor), it is likely that the air in the milking room represents a S. aureus constant contamination for the nostrils of the ewe. That stresses a possible role of air as a vehicle for spread of $S$. aureus. To assess the contamination of ambient air, sampling should be performed at a height under $51 \mathrm{~cm}$ from the floor (Vautor et al., 2003) or by means of a Surface Air System pump (Albenzio et al., 2003). 
The S. aureus PFGE typing results were presented in table 2 and 3. Some S. aureus PFGE patterns are illustrated in figure 1. PFGE is considered to be among the most reliable and reproductible wholegenome typing procedure (Tenover et al., 1994; Olive and Bean, 1999). Twenty one different patterns were found among isolates of $S$. aureus (table 3). One major pulsotype (named OV) was identified in 25 strains found in five farms: A, C, E, I and J. Four patterns were closely or possibly related to OV (same genetic lineage classified as related patterns), according to Tenover's criteria (Tenover et al., 1995), and were named OV'. The OV' patterns were found in farms B, D, E and G-J. The OV patterns were only absent in farm F. A previous study in these 10 dairy sheep farms, between October 2001 and April 2002 (Vautor et al., 2003), showed that a single clone of $S$. aureus is widely distributed both in infected mammary glands and in cheese produced from raw milk. In the present study, it is noteworthy when the $S$. aureus strains are recovered from the cheeses (farms $B, D, F, G, \ldots .$. ), they are always isolated from the nares of ewes in the flock (except for farm I). That suggests that this organism, specially when this is the dominant $S$. aureus strain (OV or OV'), readily or intermittently colonizes nares and after contaminates the udder milk and subsequently the cheese.

Our actual finding bring to the fore that ewe nasal carriage may represent a reservoir for $S$. aureus to contaminate other sites on the 
sheep dairy farm. So, if the infected mammary gland is not the only source/reservoir of $S$. aureus, control measures should continue even in herds with low to non-existent levels of $S$. aureus intramammary infections. 


\section{Acknowledgements}

The authors gratefully acknowledge the ten farmers for their collaboration.

\section{References}

Albenzio, M., Taibi, L., Caroprese, M., De Rosa, G., Muscio, A., Sevi, A., 2003. Immune response, udder health and productive traits of machine milked and suckling ewes. Small Rumin. Res. 48, 189200.

Eriksen, N.H., Espersen, F., Rosdahl, V.T., Jensen, K., 1995. Carriage of Staphylococcus aureus among 104 healthy persons during a 19month period. Epidemiol. Infect. 115, 51-60.

Hu, L., Umeda, A., Kondo, S., Amako, K., 1995. Typing of Staphylococcus aureus colonising human nasal carriers by pulsedfield gel electrophoresis. J. Med. Microbiol. 42, 127-132.

Kluytmans, J., van Belkum, A., Verbrugh, H., 1997. Nasal carriage of Staphylococcus aureus: epidemiology, underlying mechanisms, and associated risks. Clin. Microbiol. Rev. JID - 8807282 10, 505520.

Olive, D.M., Bean, P., 1999. Principles and applications of methods for DNA-based typing of microbial organisms. J. Clin. Microbiol. 37, 1661-1669.

Roberson, J.R., Fox, L.K., Hancock, D.D., Gay, J.M., Besser, T.E., 1994. Ecology of Staphylococcus aureus isolated from various sites on dairy farms. J. Dairy Sci. 77, 3354-3364. 
Roberson, J.R., Fox, L.K., Hancock, D.D., Gay, J.M., Besser, T.E., 1998. Sources of intramammary infections from Staphylococcus aureus in dairy heifers at first parturition. J. Dairy Sci. 81, 687-693.

Tenover, F.C., Arbeit, R., Archer, G., Biddle, J., Byrne, S., Goering, R., Hancock, G., Hebert, G.A., Hill, B., Hollis, R., 1994. Comparison of traditional and molecular methods of typing isolates of Staphylococcus aureus. J. Clin. Microbiol. 32, 407-415.

Tenover, F.C., Arbeit, R.D., Goering, R.V., Mickelsen, P.A., Murray, B.E., Persing, D.H., Swaminathan, B., 1995. Interpreting chromosomal DNA restriction patterns produced by pulsed-field gel electrophoresis: criteria for bacterial strain typing. J. Clin. Microbiol. 33, 2233-2239.

VandenBergh, M.F., Yzerman, E.P., van Belkum, A., Boelens, H.A., Sijmons, M., Verbrugh, H.A., 1999. Follow-up of Staphylococcus aureus nasal carriage after 8 years: redefining the persistent carrier state. J. Clin. Microbiol. 37, 3133-3140.

Vautor, E., Abadie, G., Guibert, J.M., Huard, C., Pepin, M., 2003. Genotyping of Staphylococcus aureus isolated from various sites on farms with dairy sheep using pulsed-field gel electrophoresis. Vet. Microbiol. 96, 69-79.

White, A., 1961. Relation between quantitative nasal cultures and dissemination of staphylococci. J. Lab. Clin. Med. 58, 273-277.

Zecconi, A., Piccinini, R., Fox, L.K., 2003. Epidemiologic study of intramammary infections with Staphylococcus aureus during a control program in nine commercial dairy herds. J. Am. Vet. Med. Assoc. 223, 684-688. 
